\title{
Coupling Between Heterotrophic Nanoflagellates and Bacteria in Fresh Waters: Does Latitude Make a Difference?
}

\author{
Bianca T. Segovia ${ }^{1 *}$, Carolina D. Domingues², Bianca R. Meira ${ }^{1}$, \\ Fernando M. Lansac-Toha', Paulina Fermani ${ }^{3}$, Fernando Unrein ${ }^{3}$, Lúcia M. Lobão4, \\ Fabio Roland ${ }^{4}$, Luiz F. M. Velho ${ }^{1}$ and Hugo Sarmento ${ }^{5}$ \\ ${ }^{1}$ Núcleo de Pesquisas em Limnologia, Ictiologia e Aquicultura, Universidade Estadual de Maringá, Maringá, Brazil, \\ ${ }^{2}$ Departamento de Botânica, Universidade Federal do Rio de Janeiro, Rio de Janeiro, Brazil, ${ }^{3}$ Instituto Tecnológico de \\ Chascomús, Universidad Nacional de San Martín, Chascomús, Argentina, ${ }^{4}$ Departamento de Ecologia, Universidade \\ Federal de Juiz de Fora, Juiz de Fora, Brazil, ${ }^{5}$ Departamento de Hidrobiologia, Universidade Federal de São Carlos, São \\ Carlos, Brazil
}

OPEN ACCESS

Edited by:

James Cotner,

University of Minnesota Twin Cities,

USA

Reviewed by:

Guang Gao,

Nanjing Institute of Geography and

Limnology, China

Nathalie Niquil,

Centre National de la Recherche

Scientifique, France

*Correspondence:

Bianca T. Segovia

biatsegovia@gmail.com

Specialty section: This article was submitted to

Aquatic Microbiology,

a section of the journal

Frontiers in Microbiology

Received: 05 August 2015

Accepted: 22 January 2016

Published: 11 February 2016

Citation:

Segovia BT, Domingues $C D$

Meira BR, Lansac-Toha FM,

Fermani P, Unrein F, Lobão LM,

Roland $F$, Velho LFM and Sarmento $H$

(2016) Coupling Between

Heterotrophic Nanoflagellates and Bacteria in Fresh Waters: Does

Latitude Make a Difference?

Front. Microbiol. 7:114.

doi: 10.3389/fmicb.2016.00114
Recent studies reported comparatively lower heterotrophic bacteria $(\mathrm{HB})$ abundances in tropical regions, indicating that factors involved in bacterial losses could be more relevant in the tropics. Heterotrophic nanoflagellates (HNF) are considered the main predators of $\mathrm{HB}$ in aquatic ecosystems, and one should expect higher abundances in the tropics because of differences in the food web configuration (absence of large daphnids). However, there are no comprehensive studies comparing HB and HNF abundances in a latitudinal gradient. We hypothesized that HB abundance would be lower in the tropics because HNF abundance would be higher, resulting in a tighter HNF-HB coupling. To test this hypothesis, we compiled a large dataset of HB and HNF abundances from tropical and temperate freshwater environments. We found that both $\mathrm{HB}$ and HNF abundances were lower in the tropical region, and that HNF-HB coupling does not differ between temperate and tropical regions. The lower HNF abundance and lack of coupling may be explained by a strong top-down control on HNF and/or their herbivory preference. Besides, no relationship was found between bacterial specific growth rate and either chlorophyll-a and HB abundance, indicating that bacterial losses may have an important role in tropical freshwaters. Thus, we found that HNF is likely not the main controllers of HB abundance, and that grazing by ciliates and cladocerans, together with the physiological effects of higher temperatures, may explain the high bacterial loss rates in the tropics.

Keywords: bacterioplankton, cladocera, protist, predation, latitude

\section{INTRODUCTION}

Inland aquatic ecosystems play a relevant role in the global carbon cycle (Cole et al., 2007; Tranvik et al., 2009; Raymond et al., 2013). Low latitude freshwaters, particularly wetlands, represent a high percentage of global $\mathrm{CO}_{2}$ evasion to the atmosphere compared to colder counterparts located in temperate regions (Marotta et al., 2009; Aufdenkampe et al., 2011; Barros et al., 2011; 
Abril et al., 2014; Borges et al., 2015). The disproportional importance of tropical fresh waters in $\mathrm{CO}_{2}$ net diffusion would be due to the high input of organic terrestrial carbon and further microbial heterotrophic respiration (Cole et al., 1994; del Giorgio et al., 1999), together with the higher temperatures (Kosten et al., 2010). In fact, bacterial biomass and production has been related to $\mathrm{CO}_{2}$ lake concentrations (Tadonléké et al., 2012; Fontes et al., 2013), evidencing the importance of bacterioplankton in $\mathrm{CO}_{2}$ emission dynamics. Thus, it is essential to identify the patterns and drivers of bacterial abundance, production and respiration across latitudinal gradients.

In this way, recent studies pointed out that, despite the slightly higher bacterial production in lower latitudes (Amado et al., 2013), the bacterial abundance found in those regions is lower, compared to temperate environments (Roland et al., 2010; Sarmento, 2012). This indicates that factors involved in bacterial loss would be more important in the tropics, since bacterial biomass does not seem to increase with increasing bacterial production in similar rates in both regions (Billen et al., 1990). The low bacteria:chlorophyll-a ratios found in warm waters suggest that grazing might be an important mechanism limiting bacterial abundance (Sarmento et al., 2008; Roland et al., 2010; Özen et al., 2013). These differences in HB abundance at different latitudes have been attributed, at least in part, to a higher top-down control of rotifers, ciliates, and nanoflagellates in warmer regions (Roland et al., 2010; Sarmento et al., 2010; Sarmento, 2012; Vázquez-Domínguez et al., 2012; Amado et al., 2013).

Because heterotrophic nanoflagellates (HNF) are considered the main responsible for channeling bacterial production to higher trophic levels (Fenchel, 1982; Sanders et al., 1989, 1992; Berninger et al., 1991), one should expect a higher top-down control on bacteria by the HNF in the tropics. Factors known to exert an influence on the predator-prey relationship between HNF and bacteria, such as temperature, bacterial, and HNF abundance (Peters, 1994; Vaqué et al., 1994; Gasol et al., 2002), vary widely with latitude. As temperature alters metabolic rates, it also influences all the other factors above cited, as predicted by the metabolic theory of ecology (MTE; Brown et al., 2004), which might also provide some insights on differences of microbial metabolic rates and trophic interactions between tropical and temperate regions.

The cornerstone of MTE is that metabolic rates, including grazing rates (Sarmento et al., 2010) and population growth rates (Savage et al., 2004), increase exponentially with temperature (Brown et al., 2004). For instance, bacterial abundance and production is thought to increase with increasing temperatures (White et al., 1991). However, the effects of temperature are not always straightforward, and increased temperatures may actually lead to a decrease in the abundance of the organisms, because the increased metabolic cost per individual means that a given supply of energy will support a smaller number of individuals (Brown et al., 2004; Savage et al., 2004; Sarmento et al., 2010). Yet, this assumption does not consider the effects of trophic interactions. For example, Jiang and Morin (2004) found that competition between the populations of two protists changed the outcome of temperature effects on their abundances, when compared with the isolated temperature effect on those populations. Also, Vasseur and McCann (2005) model states that temperature alone would not affect resource density in the absence of predators, implying that the effects of trophic interactions should also be taken into account.

Temperature has also been positively correlated with feeding rates, thereupon protist grazing rates on bacteria are expected to be higher with raised temperatures, since more food is required to fulfill their energy demand (Peters, 1994; Vaqué et al., 1994; Sarmento et al., 2010). Considering that tropical regions experience elevated temperatures throughout the year, bacteria might suffer a higher predation pressure, so that a larger proportion of bacterial production is taken by grazers (Sarmento et al., 2010), outbalancing bacterial growth stimulation by temperature. Indeed, in the few studies available for tropical region, HNF grazing on bacteria was found to be relatively high (Pirlot et al., 2007; Tarbe et al., 2011).

It is believed that HNF abundance in warm environments should be higher than in colder ones, owing to consistent differences in the food web structure along the latitudinal gradient (Sarmento, 2012; Özen et al., 2013). This is because in temperate environments there is a typical prevalence of largebodied cladocerans, which are able to suppress the abundance of HNF (Gasol et al., 1995; Jürgens and Stolpe, 1995; Kalinowska et al., 2015). Actually, the predation pressure of Daphnia on HNF was found to result in a lack of coupling between HNF-bacteria in temperate systems, highlighting zooplankton as crucial regulators of bacterial abundance (Gasol and Vaqué, 1993; Jürgens et al., 1994). Meanwhile in the tropics, both temperature (Havens et al., 2015) and the high predation pressure exerted by the juvenile fishes, which are almost permanently present due to fish reproduction throughout the year (Fernando, 1994; Lazzaro, 1997; Iglesias et al., 2011), favor the development of smallbodied zooplankton. Those, in turn, would not be as efficient in reducing microbial abundances as their relatives of the temperate regions, thus the assumed greater HNF abundance would account for a tighter coupling between bacteria and HNF in tropical environments (Sarmento, 2012). Accordingly, elevated temperatures increasing microbial metabolism, along with the higher abundance of HNF and lower abundance of bacteria, all concur to the idea that HNF-bacteria coupling should differ across latitudinal gradients, being stronger in the tropics.

The aim of this study was to compare HNF and HB abundances in different latitudes (temperate vs tropical), as well as the HNF-HB coupling. Taking into account that HNF grazing pressure is thought to be the main explanation for lower bacterial abundance in tropical regions, and that the lack of HNF-bacterial coupling seems to be a widespread phenomenon in the temperate ones, we hypothesized that, in the tropics, (i) HB abundance would be lower, because (ii) HNF abundance would be higher, and consequently (iii) HNF-HB coupling would be stronger. We also investigated the importance of other predators and resources (i.e., chlorophyll-a) in explaining bacterial abundance in tropical environments. In order to test these hypotheses, we compiled a large dataset of $\mathrm{HB}$ and HNF abundances from tropical and temperate freshwater environments and compared 
their abundances and the HNF-HB coupling, besides exploring other possible causes involved in bacterial losses in the tropics.

\section{MATERIALS AND METHODS}

\section{Data Compilation}

The dataset consists of 1047 observations of heterotrophic bacteria (HB) and HNF abundances from the literature in both tropical $\left(N_{\text {trop }}=381\right)$ and temperate $\left(N_{\text {temp }}=666\right)$ freshwater inland aquatic ecosystems. The data was gathered from some of the vast literature found for temperate environments as well as studies performed so far in the tropics, and encompasses a broad range of environment types, including shallow lakes, deep lakes, and reservoirs of various trophic status (Table 1). We also used abundance data of ciliates, rotifers, cladocerans, and copepods from tropical environments.

\section{Data Analysis}

\section{HB and HNF Abundance and Relationship}

To test whether HB and HNF abundances differ among tropical and temperate freshwater environments, we used nonparametric Mann-Whitney Rank Sum test. In addition, we also performed non-parametric Mann-Whitney Rank Sum test to compare median values of HB:HNF ratios between tropical and temperate environments. To examine the relationship between HNF and HB on tropical and temperate datasets, we performed model II linear regression using the major axis (MA) method (Legendre, 2014), and verified the normal distribution of the log-transformed data. We compared the slopes and intercepts for both regions using the "ma" function of the "smatr" package (Warton et al., 2012), that tests hypotheses about slope or elevation ("elev.test") based on confidence intervals comparison.

\section{Bacterial Specific Growth Rate (SGR) Relationship with Chlorophyll-a and Bacterial Abundance}

We used a dataset comprehending several tropical environments sampled in different seasons (Lobão et al., in preparation) to verify if bacterial SGR was more related to resources or predators. We estimated bacterial SGR using the equation proposed by Kirchman (2002): SGR $=\mathrm{P} / \mathrm{B}$, where $P=$ bacterial production $\left(\mu \mathrm{gC} \mathrm{L} \mathrm{L}^{-1} \mathrm{~h}^{-1}\right)$ and $\mathrm{B}=$ bacterial biomass $\left(\mu \mathrm{gC} \mathrm{L}^{-1}\right)$. We performed linear regressions to test the relationship between SGR and HB abundance, which might provide some hints about the factors controlling their abundance. The rationale is that, considering the density-dependent logistic growth of bacteria, SGR is low when bacterial abundance is reaching the carrying capacity, meaning that they are limited by resource availability. Hence, a negative relationship between SGR and abundance indicates bottom-up control. Conversely, SGR is high when bacterial abundance is far from reaching the carrying capacity. Thus, the lack of relationship between SGR and abundance indicates top-down control, so that predators could be consuming bacteria at rates equal to or higher than their production (Wright and Coffin, 1984; Gasol et al., 2002).

\section{Impact of Other Communities on HB and HNF Abundance}

We examined the effects of potential predators on HB and HNF in the tropical region. We considered the abundances of $\mathrm{HB}$ and HNF as response variables separately, and performed multiple regressions for each one. For HB, we used the abundance of the predators HNF, ciliates, rotifers and cladocerans as explanatory variables, excluding copepods, which have a very low capture efficiency of picoplankton (Wilson, 1973; Finlay and Roff, 2004; Sommer and Sommer, 2006). For HNF, we used the abundance of the predators known to exploit them as food, such as ciliates, rotifers, cladocerans, and copepods.

Data was log-transformed and all analyses were performed in R Development Core Team (2013) using the libraries "vegan" (Oksanen et al., 2015), "Imodel2" (Legendre, 2014), and "smatr" (Warton et al., 2012). Figures were made on SigmaPlot v.12 software (Systat Softare Inc.).

\section{RESULTS}

At first, we considered all data we gathered from the literature in our analyses. However, some of the studies performed in highly eutrophic environments have found extreme values of $\mathrm{HB}$ and HNF abundance, never reported before on the literature (i.e., Fermani et al., 2013, 2015). As we did not found any equivalent conditions in the tropical dataset, and since we noticed that the data from those studies were outliers, we decided to disregard those values from all our analyses. In this way, we maintained a similar distribution of points among trophic states in the temperate (oligotrophic: $16 \%$, mesotrophic: $50 \%$, eutrophic: $34 \%$ ) and tropical (oligotrophic: 19\%, mesotrophic: 45\%, eutrophic: $36 \%$ ) regions. Nevertheless, we show them in the regression figure (Figure 3) for comparison purposes.

\section{HB and HNF Abundance}

Comparing HB and HNF abundance in tropical and temperate freshwater environments, we found higher values in the temperate region for both $\mathrm{HB}(\log \mathrm{HB}: p<0.001$, Mann-Whitney $U$ Statistic $=218964.5$; Figure 1A) and HNF (logHNF: $p<0.001$, Mann-Whitney $U$ Statistic $=189579$; Figure 1B) communities.

\section{HNF-HB Relationship}

HB:HNF ratios were not significantly different between tropical and temperate environments (HB:HNF: $p=0.3049$, MannWhitney $U$ Statistic = 131703; Figure 2).

We found a significant positive relationship between HNF and $\mathrm{HB}$ for tropical and temperate regions. Comparing the regression models from both regions, we found no significant differences between the slopes, besides no differences in the confidence intervals for the intercepts (Table 2; Figure 3).

\section{Factors Controlling HB and HNF Abundances}

Linear regressions between SGR and HB abundance (Figure 4) were non-significant in most tropical systems 
TABLE 1 | Database from each literature data in tropical and temperate environments used in all analysis. *To perform the analysis of the relationship between bacterial specific growth rates, chlorophyll- ${ }^{a}$, and bacterial abundance, we used a different dataset (see below).

\begin{tabular}{|c|c|c|c|c|c|}
\hline \multirow[t]{2}{*}{ Reference } & \multirow[t]{2}{*}{$N$} & \multicolumn{2}{|c|}{ HB abundance } & \multicolumn{2}{|c|}{ HNF abundance } \\
\hline & & Minimum & Maximum & Minimum & Maximum \\
\hline Domingues et al., submitted & 46 & $5.93 \times 10^{5}$ & $6.17 \times 10^{6}$ & $1.80 \times 10^{3}$ & $2.75 \times 10^{4}$ \\
\hline Meira et al., in preparation & 21 & $3.03 \times 10^{5}$ & $2.50 \times 10^{6}$ & $6.52 \times 10^{0}$ & $2.02 \times 10^{2}$ \\
\hline Morana et al., 2014 & 21 & $1.82 \times 10^{6}$ & $4.58 \times 10^{6}$ & $2.07 \times 10^{2}$ & $1.11 \times 10^{3}$ \\
\hline Pirlot et al., 2005 & 21 & $1.66 \times 10^{6}$ & $5.63 \times 10^{6}$ & $2.99 \times 10^{2}$ & $4.08 \times 10^{3}$ \\
\hline Segovia et al., 2014 & 72 & $1.46 \times 10^{5}$ & $1.26 \times 10^{6}$ & $1.09 \times 10^{2}$ & $1.21 \times 10^{4}$ \\
\hline Segovia et al., in preparation & 106 & $4.18 \times 10^{4}$ & $2.33 \times 10^{6}$ & $1.78 \times 10^{1}$ & $1.53 \times 10^{3}$ \\
\hline Total & 381 & & & & \\
\hline Bloem and Bär-Gilissen, 1989 & 34 & $4.00 \times 10^{6}$ & $1.00 \times 10^{7}$ & $2.00 \times 10^{2}$ & $3.40 \times 10^{4}$ \\
\hline Bloem et al., 1989 & 12 & $5.42 \times 10^{6}$ & $1.45 \times 10^{7}$ & $5.40 \times 10^{2}$ & $1.05 \times 10^{4}$ \\
\hline Christoffersen et al., 1990 & 10 & $4.13 \times 10^{6}$ & $5.91 \times 10^{6}$ & $8.75 \times 10^{1}$ & $1.08 \times 10^{3}$ \\
\hline Fermani et al., 2013* & 41 & $2.34 \times 10^{7}$ & $1.08 \times 10^{8}$ & $9.40 \times 10^{3}$ & $1.12 \times 10^{5}$ \\
\hline Fermani et al., 2015* & 36 & $1.39 \times 10^{6}$ & $2.87 \times 10^{8}$ & $1.47 \times 10^{2}$ & $3.89 \times 10^{5}$ \\
\hline Finlay et al., 1988 & 6 & $8.70 \times 10^{6}$ & $2.10 \times 10^{7}$ & $5.00 \times 10^{4}$ & $1.80 \times 10^{5}$ \\
\hline Güde, 1986 & 7 & $4.10 \times 10^{6}$ & $9.40 \times 10^{6}$ & $2.30 \times 10^{3}$ & $7.20 \times 10^{3}$ \\
\hline Güde, 1988 & 9 & $3.80 \times 10^{6}$ & $9.95 \times 10^{6}$ & $1.40 \times 10^{2}$ & $7.67 \times 10^{3}$ \\
\hline Jürgens and Güde, 1991 & 19 & $4.10 \times 10^{6}$ & $1.24 \times 10^{7}$ & $1.40 \times 10^{3}$ & $2.50 \times 10^{4}$ \\
\hline Jürgens and Jeppesen, 2000 & 10 & $4.76 \times 10^{6}$ & $1.56 \times 10^{7}$ & $2.29 \times 10^{3}$ & $1.29 \times 10^{4}$ \\
\hline Munawar and Weisse, 1989 & 72 & $3.90 \times 10^{5}$ & $3.35 \times 10^{6}$ & $4.40 \times 10^{2}$ & $5.79 \times 10^{3}$ \\
\hline Vaqué and Pace, 1992 & 64 & $2.90 \times 10^{6}$ & $8.76 \times 10^{6}$ & $1.69 \times 10^{2}$ & $1.92 \times 10^{3}$ \\
\hline Weisse, 1990 & 24 & $5.69 \times 10^{5}$ & $6.56 \times 10^{6}$ & $5.40 \times 10^{2}$ & $8.11 \times 10^{3}$ \\
\hline Weisse, 1991 & 103 & $4.21 \times 10^{5}$ & $7.99 \times 10^{6}$ & $3.14 \times 10^{2}$ & $7.97 \times 10^{3}$ \\
\hline Wieltschnig et al., 2001 & 31 & $2.91 \times 10^{6}$ & $6.66 \times 10^{6}$ & $5.59 \times 10^{2}$ & $2.34 \times 10^{3}$ \\
\hline Total & 743 & & & & \\
\hline
\end{tabular}

*Data from those references were considered outliers and were not used in our analysis.

(six out of eight systems), pointing toward a regulation of bacterial numbers by predation for most systems. Taking all systems together, this relationship was not significant either.

We performed multiple regressions to evaluate the effects of potential predators on $\mathrm{HB}$ abundance. The regression model explained $28 \%$ of the variation in $\mathrm{HB}$ abundance of the tropical data and included the abundances of HNF, ciliates, rotifers and cladocerans (Table 3). The standardized regression coefficients of both HNF and rotifers were positive, thus an increase in HNF and rotifer abundance was associated with an increase in $\mathrm{HB}$ abundance, suggesting a bottom-up effect. As for the ciliates and cladocerans, we found a negative relationship, suggesting a top down effect, since an increase in ciliate and cladoceran abundance was associated with a reduction in $\mathrm{HB}$ abundance.

The best multiple regression model for HNF abundance included only ciliates and cladocerans and explained $32 \%$ of the HNF abundance variation. The standard regression coefficient of ciliates was positive, indicating a simultaneously increase in both variables. As for the cladocerans, we found a negative 


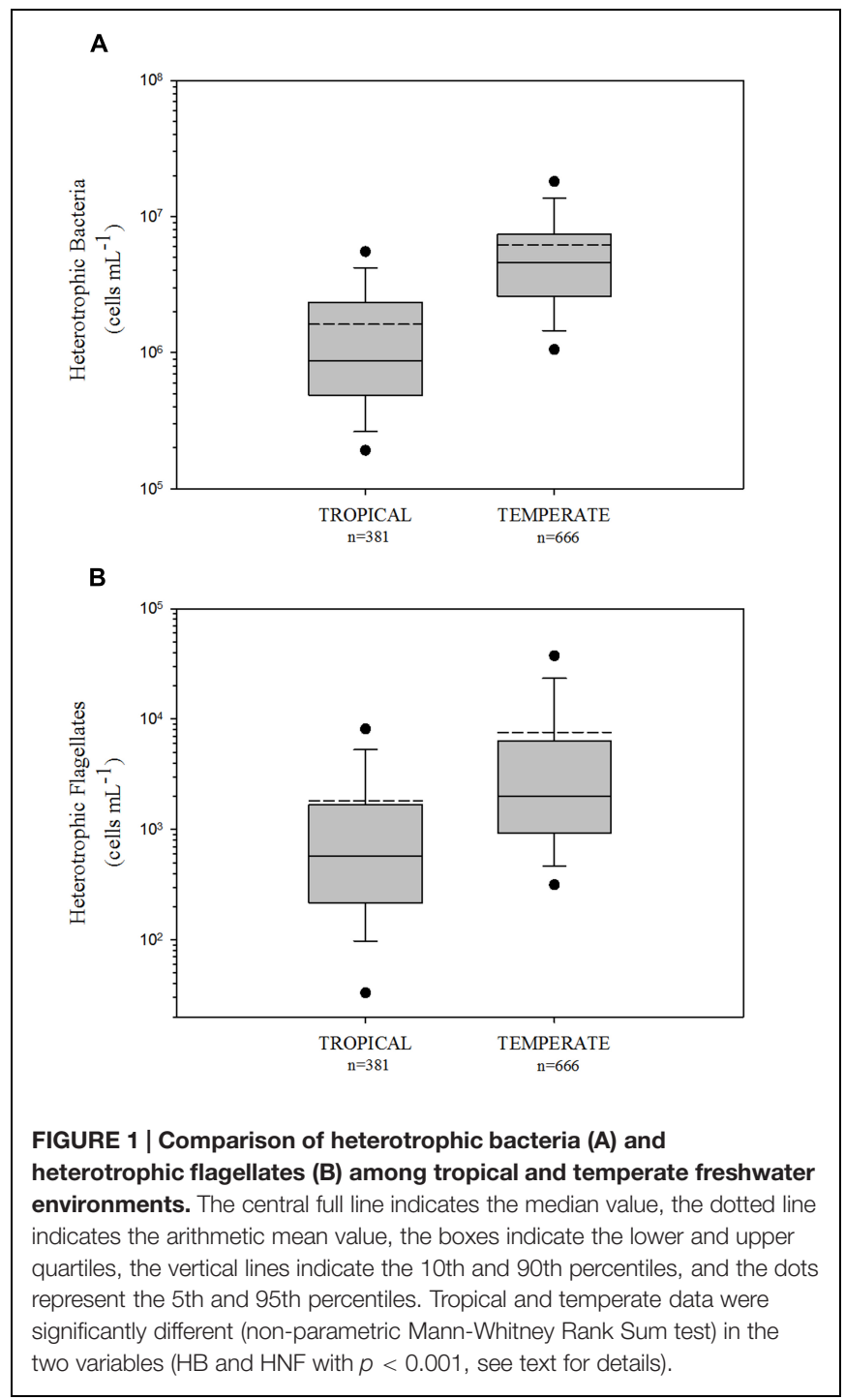

relationship, indicating a top-down effect of this group on HNF (Table 3).

\section{DISCUSSION}

We compiled for the first time a consistent HNF and HB abundance database for tropical freshwaters, and compared the abundances of those communities with the ones from the temperate environments, as well as explored probable causes of lower bacterial abundance in the tropics. We found that both $\mathrm{HNF}$ and $\mathrm{HB}$ abundances were lower in the tropics and that there is no difference in the HNF-HB coupling between those

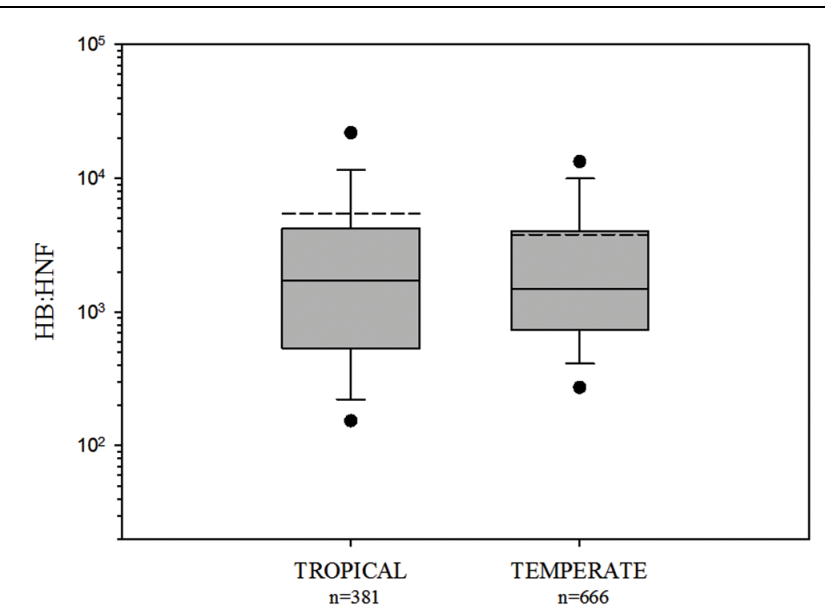

FIGURE 2 | Comparison of HB:HNF ratios among tropical and temperate freshwater environments. The central full line indicates the median value, the dotted line indicates the arithmetic mean value, the boxes indicate the lower and upper quartiles, the vertical lines indicate the 10th and 90th percentiles, and the dots represent the 5th and 95th percentiles. HB:HNF ratios were not significantly different between tropical and temperate environments (see text).

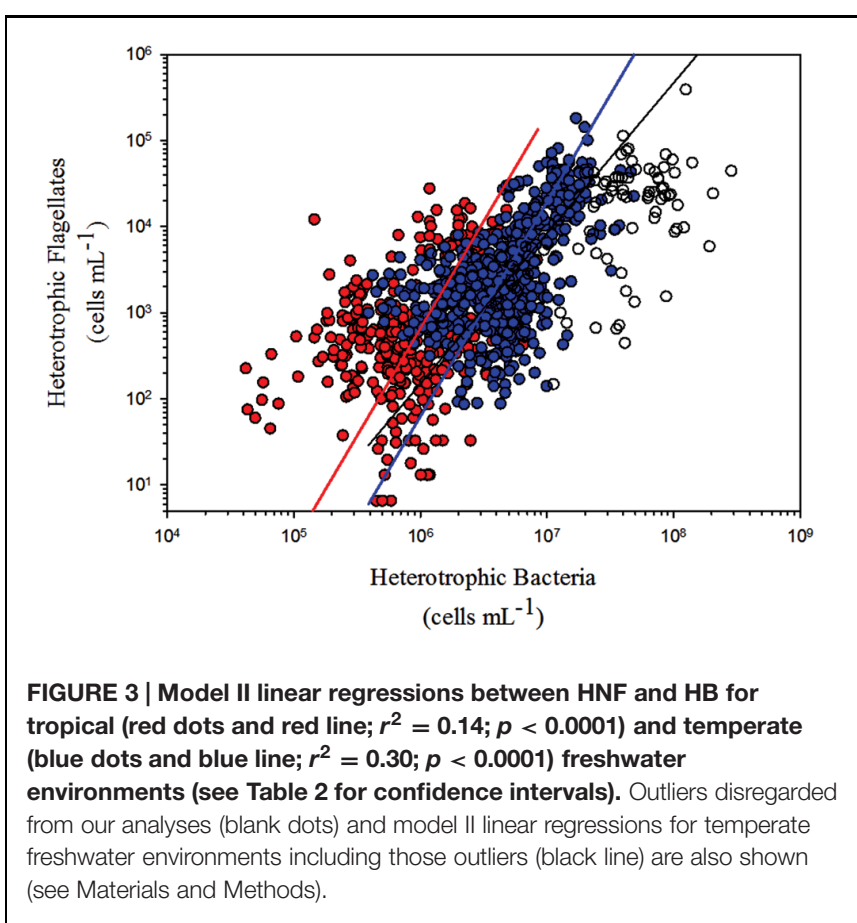

regions. Besides, $\mathrm{HB}$ abundances were apparently more regulated by predation, especially from ciliates and cladocerans.

TABLE 2 | Model II Linear Regression parameters between HNF and HB for tropical and temperate regions.

\begin{tabular}{|c|c|c|c|c|c|c|c|}
\hline LogHNF vs. LogHB & Slope & $95 \%$ (ci) & Intercept & $95 \%$ (ci) & $n$ & $r^{2}$ & $p$ \\
\hline Tropical & 2.49 & $(1.98: 3.29)$ & -12.12 & $(-16.92:-9.04)$ & 381 & 0.14 & $<0.0001$ \\
\hline Temperate & 2.48 & $(2.22: 2.81)$ & -13.13 & $(-15.28:-11.38)$ & 666 & 0.3 & $<0.0001$ \\
\hline
\end{tabular}




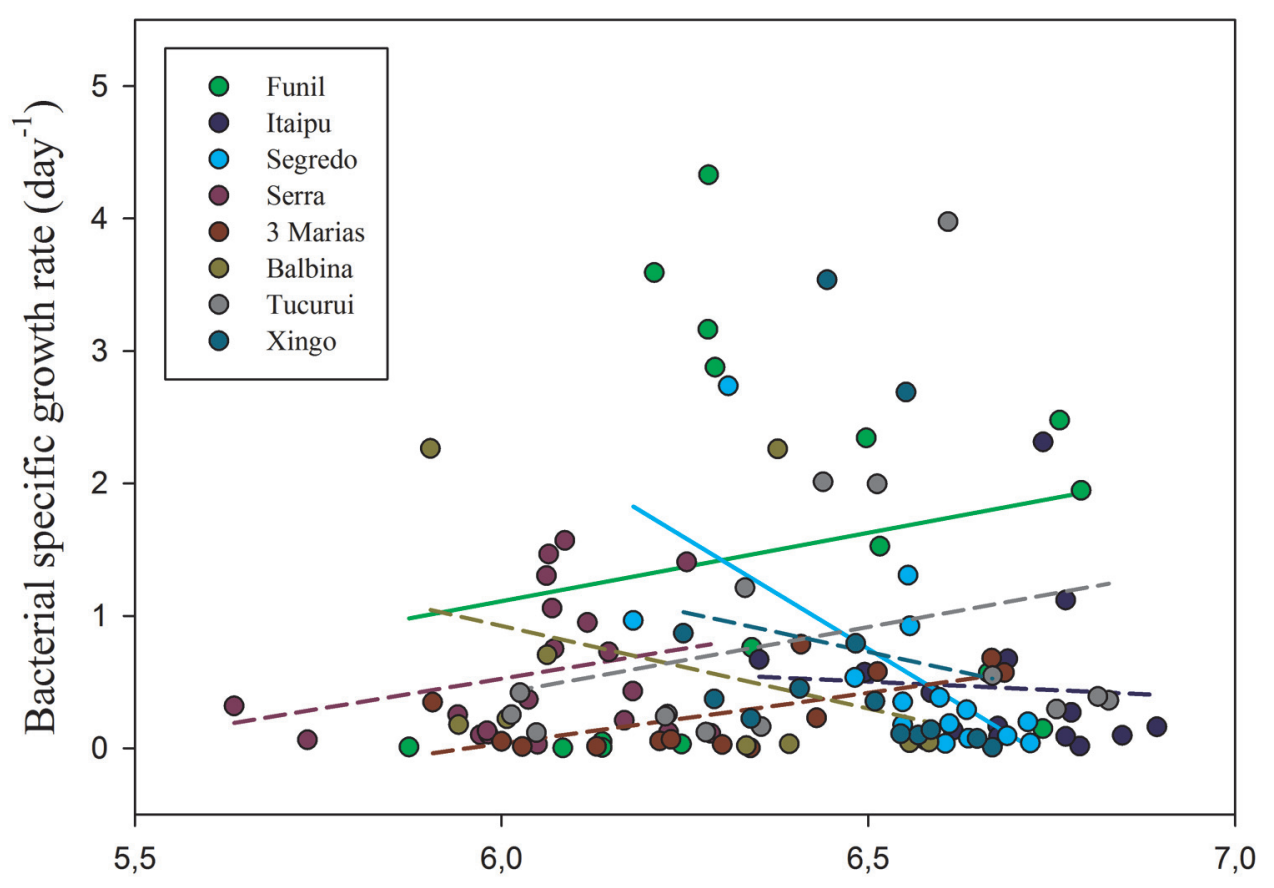

Log Bacterial Abundance (cells $\mathrm{mL}^{-1}$ )

FIGURE 4 | Relationship between bacterial SGR and HB abundance in several tropical freshwater environments. Most linear regressions (six out of eight) were non-significant, suggesting regulation by predation. One regression was positive $\left(\beta=0.13 ; r^{2}=0.30\right)$ and only one was negative suggesting resource limitation, although not a very strong one $\left(\beta=-0.18 ; r^{2}=0.49\right)$.

TABLE 3 | Regression analyses for HB and HNF abundance of the tropical region.

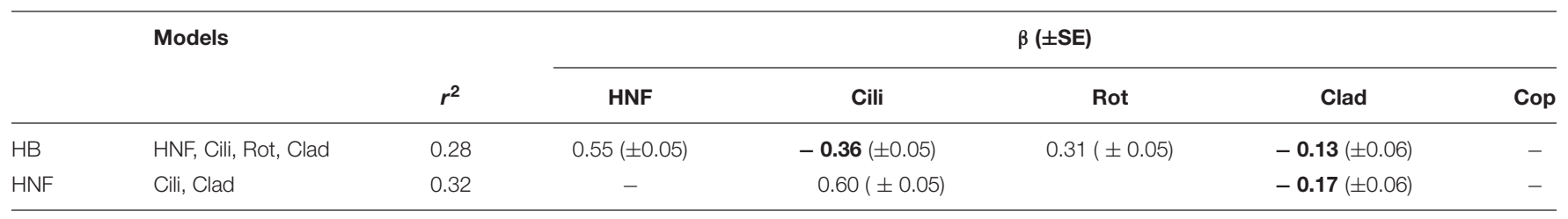

, standard regression coefficient; SE, standard error; HB, heterotrophic bacteria; HNF, heterotrophic nanoflagellates; Cili, ciliates; Rot, rotifers; Clad, cladocerans; Cop, copepods. Bold values are the negative $\beta$ values.

\section{Weak Evidence of Resource Limitation}

Evidence found in the literature suggests that bacterial growth dependence on phytoplankton derived dissolved organic carbon (DOC) supply might not always be that relevant in low latitudes. Although there is evidence that phytoplankton derived DOC would be important for the bacterioplankton of large African tropical lakes (Stenuite et al., 2009; Morana et al., 2014), low HB:phytoplankton biomass ratios have been found (Sarmento et al., 2008). In a comparative analysis using different types of Brazilian freshwater ecosystems, Roland et al. (2010) found a much weaker HB:chlorophyll- $a$ correlation in tropical when compared to the non-tropical environments. In this way, the bacteria-phytoplankton uncoupling seems to be a recurrent situation in south-American lowland lakes (e.g., Carvalho et al., 2003; Gocke et al., 2004; Rejas et al., 2005; Petrucio et al., 2006; Teixeira et al., 2011; Almeida et al., 2015), which are generally smaller and shallower, comparing to the East-African Great
Lakes. White et al. (1991) reported a rather weak correlation between SGR and chlorophyll- $a$ in freshwaters, and suggested that variations in the importance of grazing pressure may have contributed to this finding.

However, as allochthonous DOC may also constitute an important resource for HB (Tranvik, 1992), a regulation of HB by those carbon sources could also explain the weak dependency of bacteria on phytoplankton. Unfortunately, we do not have data concerning those variables, which would allow us to elucidate this point. Nonetheless, our results of non-significant relationships between bacterial SGR and HB abundance in most of the tropical systems analyzed (Figure 4), reinforce the idea that predation might be more relevant than resource limitation, whatever that resource could be. If $\mathrm{HB}$ abundance and SGR were not related, grazing was likely consuming $\mathrm{HB}$ at such a rate that it was limited by a small range of possible growth rates (Wright and Coffin, 1984; Gasol et al., 2002). Thus, we could infer that resource 


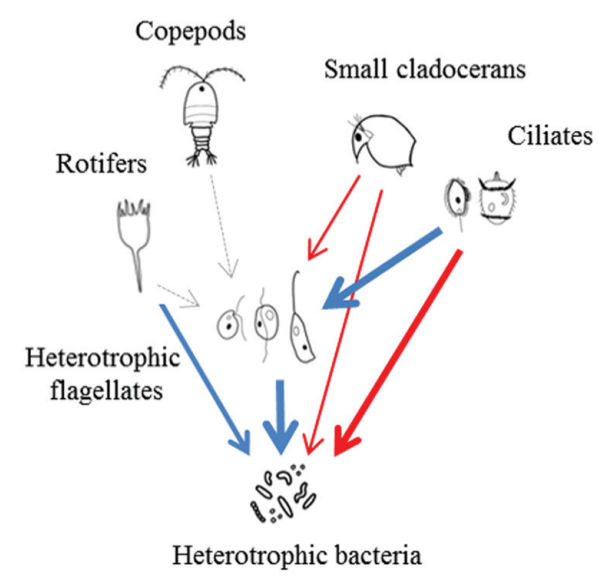

FIGURE 5 | Schematic representation showing possible impacts of predators and resources on HB and HNF in tropical regions. Dashed arrows indicate no relationship, blue arrows indicate positive and red arrows indicate negative relationships. The thickness of the arrows is proportional to the strength of the interaction.

limitation was not likely to restrain $\mathrm{HB}$ abundance in most tropical freshwater environments, and that a top-down control might prevail in these systems.

\section{HNF Abundance is Also Lower in Tropical Environments}

The assumption of a higher abundance of HNF in tropical, relative to temperate environments, was not corroborated in our study. Although large-bodied cladocerans are relatively low abundant in the tropics, the typical small bodied cladocerans, seem to exert a strong predation pressure on HNF, as evidenced by the negative standard coefficient multiple regression model (Table 3).

The impact of small-bodied cladocerans on HNF is somewhat unexpected, since in the tropics there is usually a smaller proportion of Daphniidae, which is replaced by Bosminids, Sidids, and Moinids (Dumont, 1994; Elmoor-Loureiro, 2000). However, the influence of cladocerans on the abundance of HNF was already verified in the bottom layer a tropical floodplain lake where those predators were more abundant, specially represented by Bosmina hagmanni and Ceriodaphnia cornuta (Segovia et al., 2014). In fact, the small-bodied cladocerans Bosmina, Ceriodaphnia, and Diaphanosoma were found to achieve higher weight-specific clearance rates on HNF than that of Daphnia species (Jürgens et al., 1996). Specifically, Bosmina have a particular foraging mode, different from filter-feeding, which allows certain selectivity and consequently more efficient removal of small flagellates compared to Daphnia (DeMott and Kerfoot, 1982), even at low food concentrations (DeMott, 1982). Thus, even though Daphnids are recognized as the main responsible for hampering the development of HNF in temperate ecosystems (Pace and Vaqué, 1994; Gasol et al., 1995; Jürgens and Stolpe, 1995), their low abundance in the tropics would not result in a weaker predation pressure of cladocerans on
HNF, since other small-bodied cladocerans such as the Bosminids may replace Daphnia, in the sense that they would also be able to suppress HNF effectively. As for the ciliates, we found a positive relationship with HNF, indicating that both variables are increasing. It is possible that this could be the result of the control of both HNF and ciliates by variables related to their shared resources and predators (Auer et al., 2004; Segovia et al., 2014; Domingues et al., submitted).

HNF-HB coupling in the tropics does not seem to differ from that of the temperate regions. A top-down control by cladocerans on HNF may be keeping them from reaching the high abundances they presumably would have in the tropics, blurring their effects on bacteria (Gasol and Vaqué, 1993; Gasol, 1994; Wieltschnig et al., 2001; Segovia et al., 2014; Kalinowska et al., 2015). Another possible cause for the lack of HNF-HB coupling is the use of an alternative food resource by the HNF, such as the picophytoplankton (PPP). Herbivory preference by nanoflagellates, rather than bacterivory, was verified in the large tropical Lake Tanganyika (Tarbe et al., 2011). The preference of HNF for PPP was also found in shallow floodplain lakes in the tropical region (Meira et al., in preparation). In addition, the biomass of HNF was negatively related to PPP in tropical reservoirs of different trophic states, pointing out the importance of this interaction on these environments as well (Domingues et al., submitted). To sum up, the lower HNF abundance found, together with the similar HNF-HB coupling, suggests that HNF is probably not related to the lower $\mathrm{HB}$ abundance in the tropics.

\section{Grazing by Ciliates and Cladocerans May Explain the Lower HB Abundance in the Tropics}

The variables associated with $\mathrm{HB}$ abundance in the tropics were HNF, ciliates, rotifers, and cladocerans. HNF and rotifers were positively related with $\mathrm{HB}$ abundance, which means that they are likely feeding on bacteria but are not able to suppress their abundance. On the contrary, both ciliates and cladocerans showed a negative relationship, suggesting a top-down control on $\mathrm{HB}$ abundance. As stated before, resource limitation or predation by HNF are unlikely to be the reason why bacterial abundance is lower in the tropics. Thus, the negative effect of both ciliates and cladocerans could be part of the explanation for such a pattern.

Although there is a vast literature relating the prevalence of HNF as the major bacterivores (Fenchel, 1982; Sanders et al., 1989, 1992; Berninger et al., 1991), the relatively higher importance of ciliates as predators of bacteria was also documented. The dominance of ciliates as grazers of bacteria has been reported in occasions where HNF abundance is rather low (Kisand and Zingel, 2000; Tadonléké et al., 2005; Zingel et al., 2007). Also, ciliate community structure in the tropics may differ from that of the temperate regions. It is known that bacterivory is predominant among the small oligotrich ciliates (Stabell, 1996; Šimek et al., 2000), thus perhaps features such as ciliate community composition might be playing a role on the impact of ciliates in tropical environments, where there could be a larger proportion of those bacterivorous taxa. However, more studies 
are necessary to draw such a conclusion. Another overlooked aspect would be the influence of temperature on the ciliate feeding rates. It has been shown that ciliate feeding rates increase considerably with the raise of temperature (Sherr et al., 1988; Rychert, 2011). Therefore, it is plausible to infer that the higher temperatures of the tropics may be a relevant factor.

Similarly to the impact on HNF, weight-specific filtering rates on bacteria were found to be higher for Ceriodaphnia and Bosmina than for the large Daphnia magna (Porter et al., 1983). Vaqué and Pace (1992) found that lakes dominated by large populations of Bosmina longirostris showed even slightly higher maximum values of grazing on bacteria $\left(35 \times 10^{6}\right.$ bacteria $\left.\mathrm{L}^{-1} \mathrm{~h}^{-1}\right)$ than Daphnia pulex $\left(30 \times 10^{6}\right.$ bacteria $\left.\mathrm{L}^{-1} \mathrm{~h}^{-1}\right)$, and concluded that, when in large numbers, populations of small cladocerans compensate for the lack of large Daphnids. Thus, if tropical environments are dominated by those small-bodied cladocerans, then their impact on bacterioplankton could be higher than in temperate environments. In addition, a positive relationship has been found between cladoceran filtering rate and temperature (Burns, 1969). For example, Mourelatos and Lacroix (1990) found that at a temperature of $20^{\circ} \mathrm{C}$, a Daphnia of $0.5 \mathrm{~mm}$ size filtered as much as one twice its size but at a $10^{\circ} \mathrm{C}$ temperature, suggesting that at higher temperatures those small-bodied cladocerans should have an even greater impact. Moreover, a recent study found that pelagic cladocerans significantly explained the variation in bacterial community composition in tropical South American shallow lakes (Souffreau et al., 2015), demonstrating that the predation pressure of those microcrustaceans might also be responsible for changes in bacterial community structure.

Thus, ciliates and small cladocerans seem to play a central role in the pelagic food webs of tropical freshwater environments, and the fundamental differences in the food web structure of freshwater environments in temperate and tropical environments, together with the higher temperatures of the tropical ones, likely dictate the fate of bacterial production (Figure 5).

It is worth noting that virus lysis is also recognized as a major source of bacterial losses (Fuhrman and Noble, 1995), however, few studies concerning this topic were performed in the tropics. Low virus-to-bacterium ratios and frequency of visible infected cells were found in Amazonian floodplain lakes (Barros et al., 2010; Almeida et al., 2015) and African lakes (Bettarel et al., 2006). Barros et al. (2010) suggested that these low values could be related to the registered low bacterial abundances, which restrain the rates of encounter between the virus and the bacterial host cell, resulting in a low level of viral predation. As a corollary for

\section{REFERENCES}

Abril, G., Martinez, J.-M., Artigas, L. F., Moreira-Turcq, P., Benedetti, M. F., Vidal, L., et al. (2014). Amazon River carbon dioxide outgassing fuelled by wetlands. Nature 505, 395-398. doi: 10.1038/nature12797

Almeida, R. M., Roland, F., Cardoso, S. J., Farjalla, V. F., Bozelli, R. L., and Barros, N. O. (2015). Viruses and bacteria in floodplain lakes along a major Amazon tributary respond to distance to the Amazon River. Front. Microbiol. 6:158. doi: $10.3389 /$ fmicb. 2015.00158 this explanation, the comparable lower abundances of bacteria in the tropics should result in lower loss rates by viral attack than in the temperate systems. Nonetheless, relatively high values of virus-to-bacterium ratios were found in tropical reservoirs (Peduzzi and Schiemer, 2004) and in a tropical lake (Araújo and Godinho, 2009). Thus, bacterial mortality caused by virus should be taken into account when studying mechanisms controlling bacterial abundance in tropical freshwaters in the future to elucidate this issue.

\section{CONCLUSION}

Comparing tropical against temperate data reinforced the previous findings that bacterial abundance is lower in the tropics. Moreover, bacterial specific growth rate was not related to either chlorophyll- $a$ and HB abundance, pointing to an important role of bacterial losses in the tropics. Besides, we found that HNF abundance is also lower in the tropics and that HNF-HB coupling is not different across latitudes. A top-down control on HNF and their herbivory preference may help explain the lack of HNF-HB coupling, and suggests that HNF is likely not the main cause for bacterial loss. It is possible that grazing by ciliates and cladocerans play a large role in controlling bacterial abundance in the warmer regions. However, this issue should be more investigated in future studies concerning tropical freshwater environments.

\section{AUTHOR CONTRIBUTIONS}

HS and BTS conceived and designed the study. CDD, BRM, FMLT, PF, FU and LFMV sampled and analyzed the abundance data of microbial communities from tropical/temperate freshwaters. LML and FR sampled and analyzed the bacterial specific growth rate data from tropical freshwaters. BTS wrote the manuscript with input from all coauthors.

\section{ACKNOWLEDGMENTS}

BTS is grateful for the funding and fellowships provided by the Coordination for the Improvement of Higher Education Personnel (CAPES) and the Brazilian National Council of Research and Development (CNPq). LFMV and FR have been continuously supported by CNPq grants. HS's work was supported by CNPq (Project: 474759/2013-0), FAPESP (Project: 2014/14139-3) and Furnas.

Amado, A. M., Meirelles-Pereira, F., Vidal, L. D. O., Sarmento, H., Suhett, A., Farjalla, V. F., et al. (2013). Tropical freshwater ecosystems have lower bacterial growth efficiency than temperate ones. Front. Microbiol. 4:167. doi: 10.3389/fmicb.2013.00 167

Araújo, M. F. F., and Godinho, M. J. L. (2009). Short-term variations of viruslike particles in a tropical lake: relationship with microbial communities (bacteria, ciliates, and flagellates). Microbiol. Res. 164, 411-419. doi: 10.1016/j.micres.2007.02.011 
Auer, B., Elzer, U., and Arndt, H. (2004). Comparison of pelagic food webs in lakes along a trophic gradient and with seasonal aspects: influence of resources and predation. J. Plankton Res. 26, 697-709. doi: 10.1093/plankt/fbh058

Aufdenkampe, A. K., Mayorga, E., Raymond, P. A., Melack, J. M., Doney, S. C., and Alin, S. R. (2011). Rivering coupling of biogeochemical cycles between land, oceans and atmosphere. Front. Ecol. Environ. 9:14. doi: 10.1890/100014

Barros, N., Cole, J. J., Tranvik, L. J., Prairie, Y. T., Bastviken, D., Huszar, V. L. M., et al. (2011). Carbon emission from hydroelectric reservoirs linked to reservoir age and latitude. Nature Geosci. 4, 593-596. doi: 10.1038/NGEO1211

Barros, N., Farjalla, V. F., Soares, M. C., Melo, R. C., and Roland, F. (2010). Virus-bacterium coupling driven by both turbidity and hydrodynamics in an Amazonian floodplain lake. Appl. Environ. Microbiol. 76, 7194-7201. doi: 10.1128/AEM.01161-10

Bennett, S. J., Sanders, R. W., and Porter, K. G. (1990). Heterotrophic, autotrophic and mixotrophic nanoflagellates: Seasonal abundances and bacterivory in a eutrophic lake. Limnol. Oceanogr. 35, 1821-1832. doi: 10.4319/lo.1990.35.8.1821

Berninger, U., Wickham, S., and Finlay, B. L. (1993). Trophic coupling within the microbial food web: a study with fine temporal resolution in a eutrophic freshwater ecosystem. Freshwater Biol. 30, 419-432. doi: 10.1111/j.13652427.1993.tb00825.x

Berninger, U.-G., Finlay, B. J., and Kuuppo-Leinikki, P. (1991). Protozoan control of bacterial abundances in freshwater. Limnol. Oceanogr. 36, 139-147. doi: 10.4319/lo.1991.36.1.0139

Bettarel, Y., Bouvy, M., Dumont, C., and Sime-Ngando, T. (2006). Virusbacterium interactions in water and sediment of West African inland aquatic systems. Appl. Environ. Microbiol. 72, 5274-5282. doi: 10.1128/AEM. 00863-06

Billen, G., Servais, P., and Becquevort, S. (1990). Dynamics of bacterioplankton in oligotrophic and eutrophic aquatic environments: bottom-up or top-down control? Hydrobiologia 207, 37-42. doi: 10.1007/BF00041438

Bird, D. F., and Kalff, J. (1989). Phagotrophic sustenance of a metalimnetic phytoplankton peak. Limnol. Oceanogr. 34, 155-162. doi: 10.4319/lo.1989.34.1.0155

Bloem, J., and Bär-Gilissen, M.-J. B. (1989). Bacterial activity and protozoan grazing potential in a stratified lake. Limnol. Oceanogr. 34, 297-309. doi: 10.4319/lo.1989.34.2.0297

Bloem, J., EIlenbroek, F. M., Bär-Gilissen, M.-J. B., and Cappenberg, T. E. (1989). Protozoan grazing and bacterial production in stratified Lake Vechten estimated with fluorescently labeled bacteria and by thymidine incorporation. Appl. Environ. Microbiol. 55, 1787-1795.

Borges, A. V., Darchambeau, F., Teodoru, C. R., Marwick, T. R., Tamooh, F., and Geeraert, N. (2015). Globally significant greenhouse-gas emissions from African inland waters. Nature Geosci. 8, 637-642. doi: 10.1038/ngeo2486

Brown, J. H., Gillooly, J. F., Allen, A. P., Savage, V. M., and West, G. B. (2004). Toward a metabolic theory of ecology. Ecology 85, 1771-1789. doi: 10.1890/030800

Burns, C. W. (1969). Relation between filtering rate, temperature, and body size in four species of Daphnia. Limnol. Oceanogr. 14, 693-700. doi: 10.4319/lo.1969.14.5.0693

Carvalho, P., Thomaz, S. M., and Bini, L. M. (2003). Effects of water level, abiotic and biotic factors on bacterioplankton abundance in lagoons of a tropical floodplain (Paraná River, Brazil). Hydrobiologia 510, 67-74. doi: 10.1023/B:HYDR.0000008532.71152.38

Christoffersen, K., Riemann, B., Hansen, L. R., Klysner, A., and Sørensen, H. B. (1990). Qualitative importance of the microbial loop and plankton community structure in a eutrophic lake during a bloom of cyanobacteria. Microb. Ecol. 20, 253-272. doi: 10.1007/BF02543881

Cole, J. J., Caraco, N. F., Kling, G. W., and Kratz, T. K. (1994). Carbon-dioxide supersaturation in the surface waters of lakes. Science 265, 1568-1570. doi: 10.1126/science.265.5178.1568

Cole, J. J., Prairie, Y. T., Caraco, N. F., Mcdowell, W. H., Tranvik, L. J., and Striegl, R. G. (2007). Plumbing the global carbon cycle: integrating inland waters into the terrestrial carbon budget. Ecosystems 10, 171-184. doi: 10.1007/s10021-0069013-8

del Giorgio, P. A., Cole, J. J., Caraco, N. F., and Peters, R. H. (1999). Linking planktonic biomass and metabolismo to net gas fluxes in northern temperate lakes. Ecology 80, 1422-1431. doi: 10.2307/177085
DeMott, W. R. (1982). Feeding selectivities and relative ingestion rates of Daphnia and Bosmina. Limnol. Oceanogr. 27, 518-527. doi: 10.4319/lo.1982.27. 3.0518

DeMott, W. R., and Kerfoot, W. C. (1982). Competition among Cladocerans: nature of the interaction between bosmina and daphnia. Ecology 63, 1949-1966. doi: $10.2307 / 1940132$

Dumont, H. J. (1994). On the diversity of Cladocera in the tropics. Hydrobiologia 272, 27-38. doi: 10.1007/BF00006510

Elmoor-Loureiro, L. M. A. (2000). Brazilian cladoceran studies: where do we stand? Nauplius 8, 117-131.

Fenchel, T. (1982). Ecology of heterotrophic microflagellates. iv. quantitative occurrence and importance as bacterial consumers. Mar. Ecol. Prog. Ser. 9, 35-42. doi: 10.1016/j.ejop.2008.08.002

Fermani, P., Diovisalvi, N., Torremorell, A., Lagomarsino, L., Zagarese, H. E., and Unrein, F. (2013). The microbial food web structure of a hypertrophic warm-temperate shallow lake, as affected by contrasting zooplankton assemblages. Hydrobiologia 714, 115-130. doi: 10.1007/s10750-0131528-3

Fermani, P., Torremorell, A., Lagomarsino, L., Escaray, R., Unrein, F., and Pérez, G. (2015). Microbial abundance patterns along a transparency gradient suggest a weak coupling between heterotrophic bacteria and flagellates in eutrophic shallow Pampean lakes. Hydrobiologia 752, 103-123. doi: 10.1007/s10750-0142019-x

Fernando, C. H. (1994). Zooplankton, fish and fisheries in tropical fresh-waters. Hydrobiologia 272, 105-123. doi: 10.1007/BF00006516

Finlay, B. J., Clarke, K. J., Cowling, A. J., Hidle, R. M., Rogerson, A., and Berninger, U. G. (1988). On the abundance and distribution of protozoa and their food in a productive freshwater pond. Eur. J. Protistol. 23, 205-217. doi: 10.1016/S09324739(88)80037-3

Finlay, K., and Roff, J. C. (2004). Radiotracer determination of the diet of calanoid copepod nauplii and copepodites in a temperate estuary. ICES J. Mar. Sci. 61, 552-562. doi: 10.1016/j.icesjms.2004.03.010

Fontes, M. L. S., Tonetta, D., Dalpaz, L., Antônio, R. V., and Petrucio, M. M. (2013). Dynamics of planktonic prokaryotes and dissolved carbon in a subtropical coastal lake. Front. Microbiol. 4:71. doi: 10.3389/fmicb.2013.00071

Fuhrman, J. A., and Noble, R. T. (1995). Viruses and protists cause similar bacterial mortality in coastal seawater. Limnol. Oceanogr. 40, 1236-1242. doi: 10.4319/lo.1995.40.7.1236

Gasol, J. M. (1994). A framework for the assessment of top-down vs bottom-up control of heterotrophic nanoflagellate abundance. Mar. Ecol. Prog. Ser. 113, 291-300. doi: 10.3354/meps 113291

Gasol, J. M., Pedrós-Alió, C., and Vaqué, D. (2002). Regulation of bacterial assemblages in oligotrophic plankton systems: results from experimental and empirical approaches. Antonie Van Leeuwenhoek 81, 435-452. doi: 10.1023/A:1020578418898

Gasol, J. M., Simons, A. M., and Kalff, J. (1995). Patterns in the topdown versus bottom-up regulation of heterotrophic nanoflagellates in temperate lakes. J. Plankton Res. 17, 1879-1903. doi: 10.1093/plankt/17. 10.1879

Gasol, J. M., and Vaqué, D. (1993). Lack of coupling between heterotrophic nanoflagellates and bacteria - A general phenomenon across aquatic systems. Limnol. Oceanogr. 38, 657-665. doi: 10.4319/lo.1993.38.3.0657

Gocke, K., Hernández, C., Giesenhagen, H., and Hoppe, H. (2004). Seasonal variations of bacterial abundance and biomass and their relation to phytoplankton in the hypertrophic tropical lagoon Ciénaga Grande de Santa Marta. Colombia. J. Plankton Res. 26, 1429-1439. doi: 10.1093/plankt/ fbh131

Güde, H. (1986). Loss processes influencing growth of planktonic bacterial populations in Lake Constance. J. Plankton Res. 8, 795-810. doi: 10.1093/plankt/8.4.795

Güde, H. (1988). Direct and indirect influences of crustacean zooplankton on bacterioplankton of Lake Constance. Hydrobiologia 159, 63-73. doi: 10.1007/BF00007368

Havens, K. E., Pinto-Coelho, R. M., Beklioglu, M., Christoffersen, K. S., Jeppesen, E., Lauridsen, T. L., et al. (2015). Temperature effects on body size of freshwater crustacean zooplankton from Greenland to the tropics. Hydrobiologia 743, 27-35. doi: 10.1007/s10750-0142000-8 
Iglesias, C., Mazzeo, N., Meerhoff, M., Lacerto, G., Clemente, J. M., and Scasso, F. (2011). High predation is of key importance for dominance of smallbodied zooplankton in warm shallow lakes: evidence from lakes, fish exclosures and surface sediments. Hydrobiologia 667, 133-147. doi: 10.1007/s10750-011$0645-0$

Jiang, L., and Morin, P. J. (2004). Temperature-dependent interactions explain unexpected responses to environmental warming in communities of competitors. J. Anim. Ecol. 73, 569-576. doi: 10.1111/j.0021-8790.2004. 00830.x

Jürgens, K., Arndt, H., and Rothhaupt, K. O. (1994). Zooplankton-mediated changes of bacterial community structure. Microbiol. Ecol. 27, 27-42. doi: 10.1007/BF00170112

Jürgens, K., and Güde, H. (1991). Seasonal change in the grazing impact of phagotrophic flagellates on bactéria in Lake Constance. Mar. Microb. Food Webs $5,27-37$.

Jürgens, K., and Jeppesen, E. (2000). The impact of metazooplankton on the structure of the microbial food web in a shallow, hypertrophic lake. J. Plankton Res. 22, 1047-1070. doi: 10.1093/plankt/22.6.1047

Jürgens, K., and Stolpe, G. (1995). Seasonal dynamics of crustacean zooplankton, heterotrophic nanoflagellates and bacteria in a shallow, eutrophic lake. Freshwater Biol. 33, 27-38. doi: 10.1111/j.1365-2427.1995.tb 00383.x

Jürgens, K., Wickham, S. A., Rothhaupt, K. O., and Santer, B. (1996). Feeding rates of macro- and microzooplankton on heterotrophic nanoflagellates. Limnol. Oceanogr. 41, 1833-1839. doi: 10.4319/lo.1996.41.8.1833

Kalinowska, K., Ejsmont-Karabin, J., Rzepecki, M., Kostrzewska-Szlakowska, I., Feniova, I. Y., Palash, A., et al. (2015). Impacts of large-bodied crustaceans on the microbial loop. Hydrobiologia 744, 115-125. doi: 10.1016/j.marpolbul.2015.11.022

Kirchman, D. L. (2002). Calculating microbial growth rates from data on production and standing stocks. Mar. Ecol. Prog. Ser. 233, 303-306. doi: 10.3354/meps233303

Kisand, V., and Zingel, P. (2000). Dominance of ciliate grazing on bacteria during spring in a shallow eutrophic lake. Aquat. Microbiol. Ecol. 22, 135-142. doi: 10.3354/ame022135

Kosten, S., Roland, F., Da Motta Marques, D. M., Van Nes, E. H., and Mazzeo, N. (2010). Climate-dependent CO2 emissions from lakes. Global Biogeochem. Cycle 24:GB2007. doi: 10.1029/2009GB003618

Lazzaro, X. (1997). Do the trophic cascade hypothesis and classical biomanipulation approaches apply to tropical lakes and reservoirs? Verh. Internat. Verein. Limnol. 26, 719-730.

Legendre, P. (2014). Imodel2: Model II Regression. R Package Version. 1.7-2. Available at: http://CRAN.R-project.org/package $=$ lmodel2

Marotta, H., Duarte, C. M., Sobek, S., and Enrich-Prast, A. (2009). Large $\mathrm{CO}_{2}$ disequilibria in tropical lakes. Global Biogeochem. Cycles 23:GB4022. doi: 10.1029/2008GB003434

Morana, C., Sarmento, H., Descy, J.-P., Gasol, J. M., Borges, A., and Bouillon, S. (2014). Production of dissolved organic matter by phytoplankton and its uptake by heterotrophic prokaryotes in large tropical lakes. Limnol. Oceanogr. 59, 1364-1375. doi: 10.4319/lo.2014.59.4.1364

Mourelatos, S., and Lacroix, G. (1990). In situ filtering rates of Cladocera: effect of body length, temperature, and food concentration. Limnol. Oceanogr. 35, 1101-1111. doi: 10.4319/lo.1990.35.5.1101

Munawar, M., and Weisse, T. (1989). Is the 'microbial loop' an early warning indicator of anthropogenic stress? Hydrobiologia 188/189, 163-174. doi: 10.1007/BF00027782

Nakano, S., Ishii, N., Manage, P. M., and Kawabata, Z. (1998). Trophic roles of heterotrophic nanoflagellates and ciliates among planktonic organisms in a hypereutrophic pond. Aquat. Microb. Ecol. 16, 153-161. doi: $10.3354 /$ ame 016153

Oksanen, J., Blanchet, F. G., Kindt, R., Legendre, P., Minchin, P. R., O’Hara, R. B., et al. (2015), vegan: Community Ecology Package. $R$ Package Version 2.2-1. Available at: http://CRAN.R-project.org/package=vegan

Özen, A., Sorf, M., Trochine, C., Liboriussen, L., Beklioglu, M., Sondergaard, M., et al. (2013). Long-term effects of warming and nutrients on microbes and other plankton in mesocosms. Freshwater Biol. 58, 483-493. doi: 10.1111/j.13652427.2012.02824.x
Pace, M. L., McManus, G. B., and Findlay, S. E. G. (1990). Planktonic community structure determines the fate of bacterial production in a temperate lake. Limnol. Oceanogr. 35, 795-808. doi: 10.4319/lo.1990.35. 4.0795

Pace, M. L., and Vaqué, D. (1994). The importance of Daphnia in determining mortality rates of protozoans and rotifers in lake. Limnol. Oceanogr. 39, 985996. doi: 10.4319/lo.1994.39.5.0985

Peduzzi, P., and Schiemer, F. (2004). Bacteria and viruses in the water column of tropicalfreshwaterreservoirs. Environ. Microbiol. 6, 707-715. doi: 10.1111/j.1462-2920.2004.00602.x

Pereira, D. G., Rodrigues, L. C., Lansac-Tôha, F. A., and Velho, L. F. M. (2014). Planktonic heterotrophic nanoflagellate abundance along a trophic gradient in subtropical reservoirs: influence of a bottom-up or topdown control mechanism? Acta Sci. Biol. Sci. 36, 155-163. doi: 10.4025/actascibiolsci.v36i2.19084

Peters, F. (1994). Prediction of planktonic protistan grazing rates. Limnol. Oceanogr. 39, 195-206. doi: 10.4319/lo.1994.39.1.0195

Petrucio, M. M., Barbosa, F. A. R., and Furtado, A. L. S. (2006). Bacterioplankton and phytoplankton production in seven lakes in the Middle Rio Doce basin, south-east Brazil. Limnologica 36, 192-203. doi: 10.1016/j.limno.2006. 05.001

Pick, F. R., and Caron, D. A. (1987). Picoplankton and nanoplankton biomass in Lake Ontario: relative contribution of phototrophic and heterotrophic communities. Can. J. Fish. Aquat. Sci. 44, 2164-2172. doi: 10.1139/ f87-265

Pirlot, S., Unrein, F., Descy, J. P., and Servais, P. (2007). Fate of heterotrophic bacteria in Lake Tanganyika (East Africa). FEMS Microbiol. Ecol. 62, 354-364. doi: 10.1111/j.1574-6941.2007.00396.x

Pirlot, S., Vanderheyden, J., Servais, P., and Descy, J.-P. (2005). Abundance and biomass of heterotrophic microorganisms in Lake Tanganyika. Freshwater Biol. 50, 1219-1232. doi: 10.1111/j.1365-2427.2005.01395.x

Porter, K. G., Orcutt, J. D., and Gerritsen, J. (1983). Functional response and fitness in a generalist filter feeder, daphnia magna (Cladocera: Crustacea). Ecology 64, 735-742. doi: 10.2307/1937196

R Development Core Team (2013). R: A Language and Environment for Statistical Computing. Vienna: R Foundation for Statistical Computing. Available at: http://www.R-project.org/

Raymond, P. A., Hartmann, J., Lauerwald, R., Sobek, S., McDonald, C., and Hoover, M. (2013). Global carbon dioxide emissions from inland waters. Nature 503, 355-359. doi: 10.1038/nature 12760

Rejas, D., Muylaert, K., and De Meester, L. (2005). Phytoplanktonbacterioplankton interactions in a neotropical floodplain lake (Laguna Bufeos, Bolivia). Hydrobiologia 543, 91-99. doi: 10.1007/s10750-0046824-5

Roland, F., Lobão, L. M., Vidal, L. O., Jeppesen, E., Paranhos, R., and Huszar, V. L. M. (2010). Relationships between pelagic bacteria and phytoplankton abundances in contrasting tropical freshwaters. Aquat. Microbiol. Ecol. 60, 261-272. doi: 10.3354/ame01429

Rychert, K. (2011). Dependence between temperature and clearance rate of Balanion comatum Wulff. Oceanologia 53, 623-629. doi: 10.5697/oc.53-2.623

Sanders, R. W., Caron, D. A., and Berninger, U. G. (1992). Relationships between bacteria and heterotrophic nanoplankton in marine and fresh waters - an interecosystem comparison. Mar. Ecol. Prog. Ser. 86, 1-14. doi: 10.3354/meps086001

Sanders, R. W., Porter, K. G., Bennett, S. J., and Debiase, A. E. (1989). Seasonal patterns of bacterivory by flagellates, ciliates, rotifers, and cladocerans in a freshwater planktonic community. Limnol. Oceanogr. 34, 673-687. doi: 10.4319/lo.1989.34.4.0673

Sarmento, H. (2012). New paradigms in tropical limnology: the importance of the microbial food web. Hydrobiologia 686, 1-14. doi: 10.1007/s10750-012-1011-6

Sarmento, H., Montoya, J. M., Váquez-Domínguez, E., Vaqué, D., and Gasol, J. M. (2010). Warming effects on marine microbial food web processes: how far can we go when it comes to predictions? Philos. Trans. R. Soc. B 365, 2137-2149. doi: 10.1098/rstb.2010.0045

Sarmento, H., Unrein, F., Isumbisho, M., Stenuite, S., Gasol, J. M., and Descy, J. P. (2008). Abundance and distribution of picoplankton in tropical, oligotrophic Lake Kivu, eastern Africa. Freshwater Biol. 53, 756-771. doi: 10.1111/j.13652427.2007.01939.x 
Savage, V. M., Gillooly, J. F., Brown, J. H., West, G. B., and Charnov, E. L. (2004). Effects of body size and temperature on population growth. Am. Nat. 163, 429-441. doi: 10.1086/381872

Segovia, B. T., Pereira, D. G., Bini, L. M., and Velho, L. F. M. (2014). Effects of bottom-up and top-down controls on the temporal distribution of planktonic heterotrophic nanoflagellates are dependent on water depth. Hydrobiologia 736, 155-164. doi: 10.1007/s10750-014-1904-7

Sherr, B. F., Sherr, E. B., and Rassoulzadegan, F. (1988). Rates of digestion of bacteria by marine phagotrophic protozoa: temperature dependence. Appl. Environ. Microbiol. 54, 1091-1095.

Šimek, J. C., Macek, M., Seda, J., and Vyhnálek, V. (1990). Possible food chain relationships between bacterioplankton, protozoans and cladocerans in a reservoir. Int. Res. Ges. Hydrobiol. 75, 583-596. doi: 10.1002/iroh.19900750502

Šimek, K., and Fuksa, J. (1989). Responses in bacterial activity to changing conditions in plankton - probable controlling mechanisms. Arch. Hydrobiol. Beih. Ergebn. Limnol. 33, 239-248.

Šimek, K., Hartman, P., Nedoma, J., Pernthaler, J., Vrba, J., Springmann, D., et al. (1997). Community structure, picoplankton grazing and zooplankton control of heterotrophic nanoflagellates in a eutrophic reservoir during the summer phytoplankton maximum. Aquat. Microb. Ecol. 12, 49-63. doi: 10.3354/ame012049

Šimek, K., Jürgens, K., Nedoma, J., Comerma, M., and Armengol, J. (2000). Ecological role and bacterial grazing of Halteria spp: small freshwater oligotrichs as dominant pelagic ciliate bacterivores. Aquat. Microb. Ecol. 22, 43-56. doi: 10.3354/ame022043

Sommaruga, R. (1995). Microbial and classical food webs: a visit to a hypertrophic lake. FEMS Microbiol. Ecol. 17, 257-270. doi: 10.1111/j.15746941.1995.tb00150.x

Sommer, U., and Sommer, F. (2006). Cladocerans versus copepods: the cause of contrasting top-down controls on freshwater and marine phytoplankton. Oecologia 147, 183-194. doi: 10.1007/s00442-005-0320-0

Souffreau, C., Van der Gucht, K., van Gremberghe, I., Kosten, S., Lacerot, G., and Lobão, L. M. (2015). Environmental rather than spatial factors structure bacterioplankton communities in shallow lakes along a $>6000 \mathrm{~km}$ latitudinal gradient in South America. Environ. Microbiol. 17, 2336-2351. doi: 10.1111/1462-2920.12692

Stabell, T. (1996). Ciliate bacterivory in epilimnetic waters. Aquat. Microb. Ecol. 10, 265-272. doi: 10.3354/ame010265

Stenuite, S., Pirlot, S., Tarbe, A.-L., Sarmento, H., Lecomte, M., and Thill, S. (2009). Abundance and production of bacteria, and relationship to phytoplankton production, in a large tropical lake (Lake Tanganyika). Freshwater Biol. 54, 1300-1311. doi: 10.1111/j.1365-2427.2009.02177.x

Tadonléké, R. D., Marty, J., and Planas, D. (2012). Assessing factors underlying variation of $\mathrm{CO}_{2}$ emissions in boreal lakes vs. reservoirs. FEMS Microbiol. Ecol. 79, 282-297. doi: 10.1111/j.1574-6941.2011.01218.x

Tadonléké, R., Planas, D., and Lucotte, M. (2005). Microbial food webs in boreal humic lakes and reservoirs: ciliates as a major factor related to the dynamics of the most active bacteria. Microb. Ecol. 49, 325-341. doi: 10.1007/s00248-0040232-2

Tarbe, A.-L., Unrein, F., Stenuite, S., Pirlot, S., Sarmento, H., Sinyinza, S., et al. (2011). Protist herbivory: a key pathway in the pelagic food web of lake tanganyika. Microbiol. Ecol. 62, 314-323. doi: 10.1007/s00248-011-9817-8

Teixeira, M. C., Santana, N. F., Azevedo, J. C. R., and Pagioro, T. A. (2011). Bacterioplankton features and its relations with doc characteristics and other limnological variables in Paraná River floodplain environments (PR/MSBrazil). Braz. J. Microbiol. 42, 897-908. doi: 10.1590/S1517-83822011000300008
Tranvik, L. J. (1992). Allochthonous dissolved organic matter as an energy source for pelagic bacteria and the concept of the microbial loop. Hydrobiologia 229, 107-114. doi: 10.1007/BF00006994

Tranvik, L. J., Downing, J. A., Cotner, J. B., Loiselle, S. A., Striegl, R. G., and Ballatore, T. J. (2009). Lakes and reservoirs as regulators of carbon cycling and climate. Limnol. Oceanogr. 54, 2298-2314. doi: 10.4319/lo.2009.54.6_part_2.2298

Vaqué, D., Gasol, J. M., and Marrasé, C. (1994). Grazing rates on bacteria - the significance of methodology and ecological factors. Mar. Ecol. Progr. Ser. 109, 263-274. doi: 10.3354/meps 109263

Vaqué, D., and Pace, M. L. (1992). Grazing on bacteria by flagellates and cladocerans in lakes of contrasting food web structure. J. Plankton Res. 14, 307-321. doi: 10.1093/plankt/14.2.307

Vasseur, D. A., and McCann, K. S. (2005). A mechanistic approach for modeling temperature-dependent consumer-resource dynamics. Am. Nat. 166, 184-198. doi: $10.1086 / 431285$

Vázquez-Domínguez, E., Vaqué, D., and Gasol, J. M. (2012). Temperature effects on the heterotrophic bacteria, heterotrophic nanoflagellates, and microbial top predators of the NW Mediterranean. Aquat. Microb. Ecol. 67, 107-121. doi: 10.3354/ame01583

Warton, D. I., Duursma, R. A., Falster, D. S., and Taskinen, S. (2012). smatr 3 - an R package for estimation and inference about allometric lines. Methods Ecol. Evol. 3, 257-259. doi: 10.1111/j.2041-210X.2011.00153.x

Weisse, T. (1990). Trophic interactions among heterotrophic microplankton, nanoplankton and bacteria in Lake Constance. Hydrobiologia 191, 111-122. doi: 10.1007/BF00026045

Weisse, T. (1991). The annual cycle of heterotrophic freshwater nanoflagellates: role of bottoms-up vs. top-down control. J. Plankton Res. 13, 167-185. doi: 10.1093/plankt/13.1.167

White, P. A., Kalff, J., Rasmussen, J. B., and Gasol, J. M. (1991). The effect of temperature and algal biomass on bacterial production and specific growthrate in fresh-water and marine habitats. Microbiol. Ecol. 21, 99-118. doi: 10.1007/BF02539147

Wieltschnig, C., Kirschner, A. K. T., Steitz, A., and Velimirov, B. (2001). Weak coupling between heterotrophic nanoflagellates and bacteria in a eutrophic freshwater environment. Microbiol. Ecol. 2, 159-167.

Wilson, D. S. (1973). Food size selection among copepods. Ecology 54, 909-914. doi: $10.2307 / 1935688$

Wright, R. T., and Coffin, R. B. (1984). Measuring microzooplankton grazing on planktonic marine bacteria by its impact on bacterial production. Microbiol. Ecol. 10, 137-149. doi: 10.1007/BF02011421

Zingel, P., Agasild, H., Nõges, T., and Kisand, V. (2007). Ciliates are the dominant grazers on pico- and nanoplankton in a shallow, naturally highly eutrophic lake. Microbiol. Ecol. 53, 134-142. doi: 10.1007/s00248-006-9155-4

Conflict of Interest Statement: The authors declare that the research was conducted in the absence of any commercial or financial relationships that could be construed as a potential conflict of interest.

Copyright (C) 2016 Segovia, Domingues, Meira, Lansac-Toha, Fermani, Unrein, Lobão, Roland, Velho and Sarmento. This is an open-access article distributed under the terms of the Creative Commons Attribution License (CC BY). The use, distribution or reproduction in other forums is permitted, provided the original author(s) or licensor are credited and that the original publication in this journal is cited, in accordance with accepted academic practice. No use, distribution or reproduction is permitted which does not comply with these terms. 